\title{
Croatian co-operatives' story of revival: Overcoming external obstacles
}

Božić, Jasmina; Šprajc, Ivan; Srbljinović, Armano

Source / Izvornik: Journal of Co-operative Organization and Management, 2019, 7

Journal article, Accepted version

Rad u časopisu, Završna verzija rukopisa prihvaćena za objavljivanje (postprint)

https://doi.org/10.1016/j.jcom.2019.100090

Permanent link / Trajna poveznica: https://urn.nsk.hr/urn:nbn:hr:131:236751

Rights / Prava: Attribution-NonCommercial-NoDerivatives 4.0 International/ImenovanjeNekomercijalno-Bez prerada 4.0 međunarodna

Download date / Datum preuzimanja: 2023-04-26

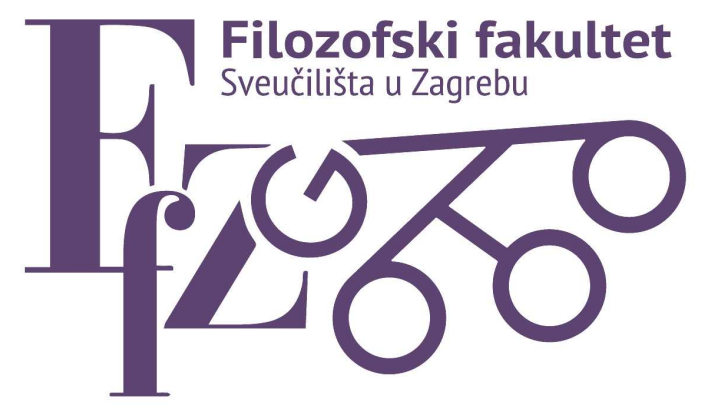

Repository / Repozitorij:

ODRAZ - open repository of the University of Zagreb

Faculty of Humanities and Social Sciences
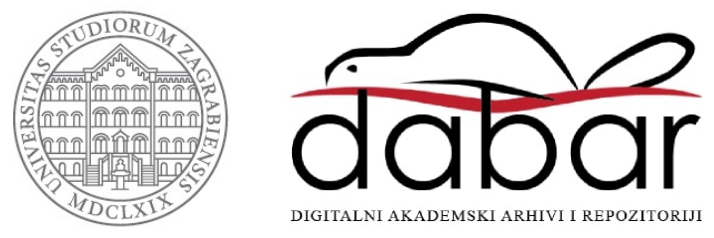
Croatian Co-operatives' Story of Revival: Overcoming External Obstacles

Jasmina Božić, Ivan Šprajc, Armano Srbljinović

Postprint

Corrected version published in Journal of Co-operative Organization and Management, Vol.

7, No. 2, 2019 


\section{Croatian Co-operatives' Story of Revival: Overcoming External Obstacles}

Abstract: While in many European countries co-operative entrepreneurship manages to fulfill its economic and social functions successfully, in Croatia a large majority of almost 1200 registered co-operatives struggle hard to accomplish in demanding market conditions while sustaining their social dimension and few succeed. Only $19 \%$ of co-operatives accounted for $96 \%$ of overall income earned by Croatian co-operatives in 2015 . We critically examine obstacles related to external legal, policy, infrastructural and other conditions that are either insufficient, completely missing or, if existent, adversely affect co-operatives. The obstacles were indicated by co-operatives themselves in a qualitative research project conducted between September 2017 and March 2018. We offer two possible explanations for the existence of the obstacles: one concerning immaturity of the Croatian institutional system, the other related to cronyism pervading the system. We see bottom-up integration of the cooperative sector, based on the principle of co-operation among co-operatives, as the best way of moving forward.

Keywords: co-operatives, crony capitalism, institutional development, qualitative research, transitional economies

\section{Introduction}

Co-operatives have been playing an important role in Croatian socioeconomic tradition since the end of the $19^{\text {th }}$ and the beginning of the $20^{\text {th }}$ century (Cvetko, 1908; Puljiz, 1992; Mataga, 1995, 2005; Borbaš \& Mikšić, 2003; Defilippis, 2005; Matijašević, 2005; Babić \& Račić, 2011; Novkovic \& Golja, 2015; Pejnović, Radeljak Kaufmann, \& Lukić, 2016). Growth of cooperative movement until the WWI was followed by stability between the two World Wars, with around 1.500 agricultural co-operatives comprising 300.000 members in the end of 1930 s, and continuity till the end of the 1950s, when state-operated huge socialist economy enterprises started overtaking co-operatives (Mataga, 2009).

Revival of co-operative alliances since mid 1970s within the socialist system of former Yugoslavia led towards the end of the 1980s witnessing the return to original democratic cooperative private organizations. Co-operatives, particularly agricultural ones, were financially helped by the state, and they were well developed, exporting goods of producers who thus obtained joint market distribution and possibilities to use common equipment of a cooperative, hence machinery ring model (Schlemper, 2014) was practiced in many local communities.

Transition to capitalist economy and the Homeland War (1991-1995) brought in their wake destructive privatization in all the Croatia's productive spheres including co-operative undertakings. Some co-operative forms failed to function altogether, for instance machinery ring continued running but rarely. Post-socialist transition period governance in Central and Eastern Europe was focused on rapid privatization of state- and socially-owned enterprises. Besides similarities in "shifting away from 'state and co-operative' ownership", pathdependence effects can also be observed in developmental trajectories of cooperative sectors in different Central and Eastern European countries (Lambru \& Petrescu, 2014, p. 731). For instance, when the Croatia's neighboring country of Slovenia gained independence and its socialist economy was transformed into capitalist one, "[c]o-operatives were not as interesting as privatized enterprises, because they did not offer so much room for individual appropriation of the existing 'social capital'” (Avsec \& Štromajer, 2015, p. 45), which allowed many co-operatives to survive predatory privatization. This was not the case with Croatian post-socialist co-operatives, many of which fell prey to predatory privatization. In the mid1990s the first Law on Co-operatives enacted in independent Croatia enabled co-operatives' employees to become members, and in many cases co-operatives' managing teams with the help of employees created narrow interest groups which overtook the control of their co- 
operative by marginalizing other members at assembly and making decisions to transfer cooperative property to trade association being established at the same time. Another phenomenon that marked the early years of co-operative movement in independent Croatia was the creation of "pseudo-co-operatives" for the sole purpose of obtaining subsidies from the Ministry of Homeland War Veterans, without any intention to start operating in earnest. Such phenomena brought in their wake the long-standing fall of all indicators of co-operative entrepreneurship (number of members, number of employees, annual income) except the number of co-operatives (Mataga, 2009).

\section{Croatian co-operative sector today}

Today, the Croatian co-ooperative sector is marked primarily by a large number of small and rather weak local co-operatives. There are 1.179 co-operatives and 7 co-operative associations registered in Croatia ${ }^{1}$ and they engage in a variety of activities, from production to consulting, with a membership of 20.483 and 2.595 persons employed. ${ }^{2} \mathrm{~A}$ large majority of Croatian co-operatives are small-scale endeavors, acting in a fragmented manner with a fairly limited market impact. In 2015 co-operatives' incomes contributed $0.5 \%$ to the national GDP, $19 \%$ of co-operatives earned a yearly income of over $500.000,00$ Croatian kunas (HRK), or approximately $67.000,00$ EUR, and those $19 \%$ were responsible for $96 \%$ of the overall income of Croatian co-operatives. On the other hand, $67 \%$ of co-operatives had no employees, and they were responsible for only $5 \%$ of the overall income of Croatian cooperatives in 2015 (Croatian Center for Co-operative Entrepreneurship, 2017).

This state of affairs is by no means exclusively Croatian problem, rather it affects the wider Southeast European region (e.g. Šoljić, Pavličević, \& Milas, 2005; Bojić \& Vapa-Tankosić, 2015; Chroneos Krasavac \& Petković, 2015). The prevalence of weak, small-scale cooperatives in the region has been explained by members' and local entities' high resistance to mergers (Cogeca, 2010). However, as will be seen in 4.2, members of Croatian cooperatives often express strong preferences toward networking and "co-operation among cooperatives" (ICA, 1995, Principle no. 6; see also Novkovic, 2008; Jussila, 2013), if not toward outright mergers, but they also complain of insufficient institutional support from national, regional and local governmental bodies in this regard.

Another set of major problems that adversely affect business environment in Croatia relate to the demise of Agrokor Corporation in 2017 (Dalić, 2018; Ivanković, 2018), which afflicted the businesses of numerous co-operatives. For co-operatives, the Agrokor Consortium's collapse manifested in losing distribution lines and strategic partners, as many co-operatives, particularly agricultural ones, had distributed their products through Konzum, national retail chain store and one of the Agrokor Corporation's most successful companies.

The demise of the Agrokor Corporation intensified discussions of crony capitalism, which had already been identified as one of the main obstacles to Croatia's economic development (Franičević \& Bićanić, 2007; Stubbs \& Zrinščak, 2015; Švarc \& Lažnjak, 2017; Kotarski \& Petak, 2019) and also played a major role in Agrokor's mismanagement (Ivanković, 2018). Besides indirect effects on the suppliers, detrimental effects of cronyism on co-operatives have often been much more direct, as when one of our research participants reported on

\footnotetext{
${ }^{1}$ According to the Record of Co-operatives and Co-operative Associations (Croatian Center for Cooperative Entrepreneurship, 2018). However, different sources provide different numbers. According to the Croatian Bureau of Statistics (2018), there are 3.514 co-operatives, of which 979 are active.

2 Data on overall numbers of co-operatives' members and employees are from the Annual Report on the State of Co-operative Entrepreneurship in 2016 (Croatian Center for Co-operative Entrepreneurship, 2017). Taken together, the data on membership and number of co-operatives show prevalence of small enterprises in the sector, which also reflects the overall structure of the Croatian economy. Small enterprises employed more than a half of all the employees in Croatia in 2015 and their share in the total income was 35.4\% (CEPOR, 2017).
} 
destruction of a promising co-operative by local clientelist patrons connected to political establishment (13:77). ${ }^{3}$

Whereas many scholars see market liberalization as the main cure for crony capitalism (e.g. Dalić, 2018; Šonje, 2019), we are not convinced of the effectiveness of market reforms in curbing cronyism. There have been several waves of market liberalization in Croatia since its gaining independence and yet the crony capitalism does not seem to subside. Generally, we believe that a more effective cure for cronyism may be found in greater democratization of the economic sphere because greater public oversight of and members' participation in management processes would make cronyism easier to expose and harder to sustain. We see development of co-operatives, and particularly "one-member-one-vote" rule of cooperative decision-making (ICA, 1995; Reynolds, 2000), as an important element of democratization processes in the economic sphere (Stiglitz, 2009; Restakis, 2010; Cheney, Santa Cruz, Peredo, \& Nazareno, 2014). ${ }^{4}$ In line with such a way of reasoning, this study has been designed to allow the voices of the members of co-operatives to be heard.

Although there have been several reviews of the state of the co-operative sector in Croatia (Petak, 2005; Babić \& Račić, 2011; Golja \& Novkovic, 2014; Pejnović et al., 2016), some of which are really comprehensive (Mataga, 2009, 2014; Pavličević, 2010), none of these studies included systematic empirical qualitative research on a sample covering all historical Croatian regions, all sorts of cooperatives by field of activity, and including cooperatives' leaders and members. Our research group at the Department of Sociology, Faculty of Humanities and Social Sciences, University of Zagreb undertook a qualitative research project "Success Factors and Cooperation Models of Co-operatives in Croatia" from September 2017 to March 2018. The main objective of the project was to obtain a broad overview of the current state of the co-operative sector in Croatia.

In this paper we focus on external obstacles to co-operatives' development indicated by our research participants. After briefly describing the research method, we review empirical results concerning various categories of obstacles. We suggest remedial actions that could be taken by relevant state and/or local government bodies to support co-operatives in overcoming those obstacles. We offer two explanations as to why there are so many obstacles in the Croatian co-operative sector. According to the "childhood illnesses" argument, Croatian institutional system is insufficiently mature and this immaturity is often accidentally reflected in inadequacies and obstacles to development of co-operatives.

According to the "unfit-for-cronyism" argument, the Croatian co-operative sector is, on one hand, too small and insignificant to be interesting to crony structures within the institutional system and, on the other hand, too incompatible in its co-operative values and principles with the crony structures merely seeking to protect their privileged status within the current system. Finally, we observe that the principle of co-operation among co-operatives may be crucial for bottom-up integration of the sector and overcoming numerous obstacles to its development.

Broadly speaking, this article starts from the so-called "resource dependence perspective", stressing the context in which organizations - in this case, co-operatives - operate (Pfeffer \&

\footnotetext{
${ }^{3}$ Hereafter, whenever a research participant is cited, the first number in parentheses is the participant's ID, and the second number is the beginning line number of the cited excerpt in the MAXQDA project file containing the transcripts of the interviews. Translations from Croatian to English are ours.

${ }^{4}$ We have to keep in mind, however, that cooperatives' struggle for economic success and growth may also induce an erosion of participatory practices and alignment to conventional corporate structures (Sivertsen, 1996; Rybnikova \& Hartz, 2014). Yet, "regeneration" of "degenerated" cooperatives is also possible (Storey, Basterretxea, \& Salaman, 2014).
} 
Salancik, 1978; Davis \& Cobb, 2010), whereas a companion paper will take the so-called "resource based view" (Barney, 1991), focusing on the co-operatives' internal resources. ${ }^{5}$

\section{Method}

\subsection{Participants}

We conducted altogether 49 semi-structured interviews with leaders or members ${ }^{6}$ of 45 cooperatives from all parts of Croatia: 4 co-operatives from Eastern Croatia, 7 from Northern Adriatic and Lika, 9 from Northwestern Croatia, 19 from Central Croatia, and 6 from Central and Southern Adriatic.

As noted elsewhere (Golja \&Novkovic, 2014; Novkovic \& Golja, 2015), Croatian official categorization of co-operatives is very much non-systematic and even confusing. First, the Croatian Law on Co-operatives classifies co-operatives by several criteria, for instance field of activities (e.g. agricultural, crafts, fishery etc.), social or other (social are those that employ or engage e.g. persons with disabilities, long unemployed persons, or other persons of reduced working capacities or lacking means for living), etc. Furthermore, war veterans' cooperatives are regulated by the Law on Croatian Homeland War Defenders and their Family Members. ${ }^{7}$ In addition, there are forms of co-operatives not mentioned by the Law that nevertheless exist in Croatia, e.g. students' co-operatives. The National Annual Report on Co-operative Entrepreneurship in 2016 states that by activity field there are $41 \%$ of agricultural co-operatives, $17 \%$ of processing co-operatives, $15 \%$ of services co-operatives, $10 \%$ of commerce co-operatives, $7 \%$ of construction co-operatives, $6 \%$ of tourism cooperatives, $3 \%$ of fishery co-operatives, and $1 \%$ of co-ooperatives with "unknown" activities (Croatian Center for Co-operative Entrepreneurship, 2017). This classification again fails to mention many kinds of co-operatives, such as architectural, techno or housing co-operatives. Yet these clearly exist, for instance, we found eleven energy co-operatives registered and active in Croatia. Second, as co-operatives are classified by various criteria, there are significant overlaps among different categories of co-operatives, for instance, a co-operative may be war veterans' by membership, agricultural by activity field, and social by persons it employs or engages. Third, there are co-operatives' covering several fields of activity, for instance, many co-operatives are registered for agriculture, food processing, as well as services. Fourth, due to business instabilities, the number of co-operatives in each category varies from year to year as some co-operatives enter bankruptcy procedures, others become inactive, while new ones are being established. Yet, the official statistics does not seem to keep pace with these changes. Fifth, sheer numbers tell little of a co-operative's relative importance, for instance, there are few finance co-operatives, hence they are not mentioned as a separate category either in the Law or in the National Annual Report on Co-operative Entrepreneurship. However, the Co-operative for Ethical Financing is the strongest Croatian co-operative. For all these reasons, we are able to report only approximately about our sample reflecting the population, as our sample comprised 23 agricultural co-operatives, 6 social co-operatives, 2 co-operatives that are both agricultural and social, 2 architectural, 2 crafts co-operatives, and 1 students', publishing, media, woodworking, techno, housing,

\footnotetext{
${ }^{5}$ Street and Cameron (2007) provide a detailed account of differences and similarities between the two views in the context of small business enterprises, whereas Mazzarol, Mamouni Limnios, and Reboud (2013) were, to our knowledge, the first to discuss and apply those views in the context of cooperatives.

${ }^{6}$ There were 30 directors, 10 ordinary members, 1 president of supervisory board, 2 members of supervisory board, 2 presidents of general assembly, 1 business development manager, 1 project manager, 1 employee who was not a member, and 1 interviewee who identified himself as a "member of management". As most of the Croatian co-operatives are small, and as we contacted the cooperatives through official channels of communication via e-mail, we have good reasons to believe that even in cases of ordinary members, we interviewed persons who were among the most active in their respective co-operatives.

${ }^{7}$ War veterans' co-operatives are used as a tool for reintegration of war veterans into the workforce, so this category is largely a policy construct (Golja \& Novkovic, 2014; Novkovic \& Golja, 2015).
} 
finance, energy, fishery and food processing co-operative. Moreover, among those cooperatives, 17 were war veterans' by membership. Most of these were agricultural by their activity field.

\subsection{Instruments, data collection and data analytic strategy}

On the basis of extensive theoretical and empirical literature review (Petak, 2005; Tratnik, Radinović, \& Žutinić, 2007; Mataga, 2009; Pavličević, 2010; Babić \& Račić, 2011; Stanojević, 2015; Pejnović et al., 2016) we constructed research protocol for a semi-structured interview. It included introductory questions, questions related to co-operative's goals, its organization, decision-making, assessment of success, support of the national and local authorities, advantages and disadvantages of co-operatives, cooperation and networking, satisfaction, and plans for future. Some specific questions concerning the potential of agricultural cooperatives to bring about renewal of Croatian agriculture were posed to agricultural cooperatives' representatives only. Ethical approval for the study was obtained from the Research Ethics Committee of the Department of Sociology, Faculty of Humanities and Social Sciences, University of Zagreb. The interviews typically lasted for around 45 minutes. They were audio recorded and transcribed upon completion. The transcripts were imported into the qualitative data analysis software MAXQDA 12.

Interview data were analyzed by using thematic analysis approach (Guest, MacQueen, \& Namey, 2011). After transcribing interviews, initial codes were generated through comparison of data segments with one another, and subsequently codes were joined together into themes; identified themes were reviewed and refined by checking whether sufficient data support them, and whether initial themes overlap or they are mutually distinctive (Braun \& Clarke, 2006). In this paper we focus in detail on the theme of external obstacles to Croatian co-operatives' functioning. Analysis and interpretation of thus organized bottom-up data necessitated insights from sociological and economic theoretical and empirical research, historical and legal studies.

\section{Results}

Cooperatives today need to operate in an increasingly competitive market. Most of our research participants, viz. co-operative leaders and members, acknowledge this reality and are aware of the fact that their cooperatives' success is largely dependent upon the development of a successful business model and a thriving business environment. Yet, among the most frequent external obstacles to co-operatives' smooth working, raised by our research participants, were unfair competition and predatory pricing:

"Competition is tougher and tougher. Because now, besides us, there are five or six firms with buying stations in the same area. Furthermore, excessive imports, particularly of goods of suspect quality, cut the prices of our domestic products. As far as I know, the situation is dire. For example, in 2006, we had the only buying station in this area and it's not the case anymore. There are firms which previously had other core businesses and which are, of course, financially much more potent, and obviously they can often offer higher prices, and they do it intentionally to weaken the competition as much as they can." (19:49).

The co-operatives' claims are probably right, but there is nothing much that can be done in that regard. Predatory pricing can be notoriously difficult to prove, so it is not realistic to expect from small cooperatives to bear the costs of protracted legal disputes with highly uncertain outcomes. Therefore, a more pragmatic approach requires consideration of other ways in which co-operatives may improve their chances on a competitive market.

Generally, the co-operative model can be successful when (1) acting as individual market agents, members face high transaction costs in selling their products or services, (2) there is a need to achieve economies of scale and strengthen bargaining power, and (3) there is direct or indirect institutional support (Bijman, 2018). Bijman (2018) also argues that (1) and (2) may not be sufficient in the absence of (3). Moreover, the necessity of (3) might be 
particularly pronounced in small markets such as the Croatian one, where it is especially hard to achieve economies of scale. It is understandable that in such circumstances cooperatives need some sort of institutional support and many Croatian co-operatives hold that they should enjoy certain market advantages. At the very least, the institutions should not set up additional obstacles to the development of the co-operative model, which, as the following discussion will show, is currently not the case in Croatia.

\subsection{Inadequate legal framework}

Many research participants expressed objections to the national legal framework regulating co-operatives. They claim that laws are not mutually harmonized and occasionally fail to distinguish among different legal subjects, such as co-operatives vs. associations. Cooperatives are also generally claimed to offer few advantages and multiple disadvantages in terms of higher administrative burden than, e.g., family farms.

\subsubsection{Legal uncertainty and inconsistency}

Frequent amendments to relevant laws regulating co-operatives and having impact on their operation, such as tax and financial law, increase unnecessary administrative burdens upon co-operatives, and also increase financial costs, as adjustments to new legal provisions, particularly those related to changes in legal status and tax requirements, are usually costly. Frequent amendments also cost time that is increasingly devoted to secondary - most often bureaucratic - aspects. One of the participants vividly illustrated opportunity costs of the paperwork burden by saying: "We produce papers, instead of food" (6:22).

An illustrative example of frequent modifications of legal framework concerns the Law on Cooperatives which came into force in 2011 (Official Gazette, 2011). Since then it has already been amended three times, in 2013, 2014, and 2018. Although all those amendments were but minor in text, they nevertheless had significant consequences as they established the Croatian Center for Co-operative Entrepreneurship, modified certain co-operative principles, changed the ways of using co-operatives' profits, etc.

Frequent changes of relevant laws often lead to inconsistencies among those laws. For example, the Law on Cooperatives enforced the cooperative principles on a very high level at first, the Law prescribed $30 \%$ of the surplus to be allocated for development of a cooperative, later this percentage was decreased to $20 \%$ - while the supporting instruments (e.g. tax credits, reliefs and/or exemptions) that would "compensate" cooperatives for their (greater) contribution to wider social benefits or goals, did not follow. In conclusion, it would be more desirable that the laws change only when changes are really necessary, and that each change is carefully thought out in advance, including the preparation of the accompanying supporting instruments.

\subsubsection{Tax laws}

The most frequent objections concerning tax laws relate to rates of tax burdens (too high tax rate of VAT and income tax); taxing of all intra co-operative relations, e.g. VAT is paid even in transactions between a co-operative and its members, and both VAT and income tax are paid in all transactions within a co-operative; non-recognition in tax regimen of co-operative's legal obligation to use part of its income as required by law (legally regulated use of income); as well as introduction of additional and special taxes on certain products (e.g. alcoholic drinks). As co-operative members put it:

"The problem is that co-operatives are constantly being placed on the same footing as firms. The law requires co-operatives to clearly limit payment of gain to its members, as at least $20 \%$ of profit must be invested into co-operative development fund and another at least $5 \%$ into members' deposits fund - the problem is that these costs are not exempted from being taxed as invested profits." (26:30).

"Here co-operatives are treated equally as commercial companies. Co-operatives are commercial companies in terms of business, yet they are also social associations and 
they have numerous social advantages. For instance, we have double taxing, you are a co-operative member and you sell your goods to your co-operative. You charge the co-operative your price plus VAT, then the co-operative further charges adding VAT etc. Intra-co-operative relations should be regulated so that they are not subject to taxation." (22:66).

One more closely connected set of objections involves the application of accounting regulations, mostly due to non-acknowledgement of co-operatives as a distinctive category of organizations:

"There is a big problem, as we do not have a law on co-operatives' accounting, but we use the general Law on Accounting that covers accounting of companies, which is absurd as the two are unrelated... For example, we obtain a substantial sum from an EU fund, e.g. 5 million Croatian kunas. Say we have to invest into premises owned by our member. What happens? According to the Law on Accounting, we are obliged to charge that member for everything we invest into his/her premises. The co-operative does not own these premises... If we rent some premises from municipality, town or from a private person, the Law on Accounting requires that we charge them if we invest into the rented premises. However, in this case we invested the money obtained from an EU fund. The EU accounting control comes to warn us: 'Sir, how come that you charged for what you have invested from the EU fund? Double financing is prohibited!' The Law on Accounting obliges us to charge the owner of rented premises what we have invested into them." (7:56).

Therefore it is visible that co-operatives advocate a distinctive status in tax law and accounting, as well as tax reductions for co-operatives. Some of our participants advocate a single, overarching regulatory framework for all aspects of co-operatives' activities:

"If a cooperative wants to employ someone, it cannot get financial stimulus for employment from the Employment Agency since employment by co-operatives is regulated by some law by the third ministry. We want a single umbrella law for cooperatives, so that I shall not have to visit five ministries where everyone is astonished and no one knows how to answer my question." (22:66).

All the objections mentioned above are justifiable from co-operatives' perspective. However, taxing issues are primarily regulated in tax legal provisions. The Ministry of Finance holds that taxing issues should be dealt with exclusively in taxing regulations, thus it is difficult to regulate taxes by special legislation. Taxing authorities deem they would lose precedence if some taxing matters were covered by special legislation, and tax system would lose clarity due to the rule that special legislation has precedence over general legislation (Lex specialis derogat legi generali). Therefore it is highly unlikely that the tax status of co-operatives would be modified through a separate legislation on co-operatives. Rather, the Ministry of Economy, Entrepreneurship and Crafts should try to improve co-operatives' tax status primarily through amendments of the existing taxing and accounting regulatory frameworks that would clearly recognize co-operatives as a distinctive type of enterprise. The main guiding principles to be applied when drafting such amendments should include avoiding double taxation; avoiding taxation of investments into co-operative development funds; and availability of tax credits, reliefs and/or exemptions for co-operatives contributing to wider social benefits.

\subsubsection{The Law on Co-operatives}

Some provisions of the Law on Co-operatives have actually prevented co-operatives' development. Firstly, the latest series of amendments to the Law raised the minimal membership fee to 1.000,00 HRK (approximately 135,00 EUR), the amount which in participants' view acted as a disincentive both to the establishment of co-operatives and to potential new members' entrance. Secondly, provisions on consequences of a co-operative's liquidation or bankruptcy discourage local self-government units from supporting local cooperatives. Article 47 determines that upon a co-operative's liquidation or bankruptcy, once 
its dues towards members and creditors are settled, all remaining assets are transferred to its local self-government unit, which should further transfer these assets either to some existing or to a newly established co-operative acting in the same local area and in the same field of activities, through tender, and upon approval of a responsible state body depending on a co-operative's field of activity. Failing this, after one year the local self-government unit is bound to use the assets for the development of co-operative entrepreneurship. This legal arrangement clearly deters towns and municipalities from supporting local co-operatives. In participants' own words:

"If we get liquidated, or transform the co-operative into some other society, than the assets should be transferred to local self-government unit, which is rather strange... Frequently one thinks that the interest of local self-government unit is that you fail/perish so that it seizes something, rather than to help you. Quite weird!" (4:68).

Hence the co-operative members and leaders rightfully deem that these two provisions should be amended. Both discussed provisions may easily be amended as they stem solely from the Law on Co-operatives and do not collide with other legal areas. For instance, future regulation might allow for membership fees of different levels depending on the category of a co-operative, e.g. profit vs. non-profit co-operatives, cooperatives that are social enterprises, etc. One may also note that co-operative legal frameworks in many countries do not stipulate the amount of minimal membership fee at all, but leave this decision entirely to the members.

Furthermore, co-operatives' assemblies might be entitled, in case of liquidation or bankruptcy, to designate the recipient of their assets among several kinds of legal subjects having similar objectives, just as associations' assemblies are entitled to do. So, the assetstripping provisions would be preserved, but the actual asset-stripping decision would respect the will of the members. The gist of this proposal is to reduce the influence of public authorities over liquidated/bankrupt co-operatives' asset transfers, reduce bureaucratized procedures, and enhance the co-operative principles, particularly those of co-operation among co-operatives and democratic control.

\subsubsection{Employment and retirement insurance regulations and various tender rules (except public procurement)}

Various EU tenders frequently exclude co-operatives from their lists of potential applicants either due to the fact that the majority of co-operatives are not non-profit organizations, or due to certain rules banning conflict of interest. The first objection could be partly prevented by founders of a co-operative opting for not-for-profit status of a co-operative, as provided by Article 38 of the Law on Co-operatives. The second objection could be remedied by including in individual co-operatives' statutes the prohibition of competition among co-operative's members, employees and managers in terms of prohibiting their individual involvement, without co-operative assembly's consent, in identical activities as those of a co-operative (opportunity provided for by Article 39 of the Law on Co-operatives).

Another set of objections originates from regulations on rights of unemployed or retired persons. Our participants argued that different statuses, such as co-operative member and unemployed person status, or co-operative member and retired person status, should not be mutually exclusive, rather they should go hand in hand with each other. Currently unemployed persons lose their unemployment benefits if they become members of a cooperative. In the same way, in general, retired persons cannot continue to be co-operative members. These restrictions hold for any type of membership in a co-operative and they adversely affect co-operatives' efficiency. This is a problem of the lawmakers' lack of understanding that a co-operative member need not hold employment contract with a cooperative, and one of the reasons why consumer cooperatives are scarce, for example. A consumer co-operative membership should not be related to employment status and unemployment benefits.

Looking for a solution, let us first note that the Law on Retirement Insurance in Article 99, paragraph 3 already enables Croatian Homeland War veterans to receive their pensions 
while acting as directors of co-operatives on voluntary basis. Such possibilities should be further extended to make the status of a co-operative member compatible to other statuses, such as unemployed persons, co-operative employees or leaders, available to all. Normative extension of compatibility of different statuses with co-operative membership, under certain conditions, may be enforced either through the Law on Co-operatives, or through relevant special legislation. We hold that these amendments should be enacted.

\subsubsection{Public procurement regulations}

Agricultural co-operatives' representatives hold that in public procurement procedures, particularly those started by local self-government units or public institutions owned by local self-government units, bids by local co-operatives should be decided on criteria of quality and origin of agricultural products. Thus local co-operatives would obtain precedence in entering contracts with local authorities or their public institutions.

Indeed, the new Public Procurement Law, in force since the beginning of 2017, in Article 284, paragraph 7, has already provided for quality or non-financial criteria in establishing economically most favorable bid. Thus the Law requires that seasonal, ecological, whole, sustainably produced and processed food, ensuring freshness or less environmental burdens (shorter and less transportation, smaller packaging, ecological packaging including that of recycled materials packages etc.) are valued in determining criteria of public procurement for agricultural products and food. Although this provision is formulated somewhat vaguely, still it created obligation to all purchasers, including local self-government units, to include among criteria of economically most favorable offer the mentioned criteria that enable higher competitiveness of domestic food and agricultural products' producers. The provision opens an opportunity for co-operatives' more successful participation in public procurement procedures.

However, in practice the provision all too often remains unimplemented. Many public procurement tenders for agricultural and food products still fail to include the criteria from Article 284, paragraph 7. Moreover, bodies responsible for the implementation of Public Procurement Law have done little towards facilitating operationalization of the mentioned provision. In public procurement procedures appellate deadlines are relatively short, most often amounting to 10 days, and an appellate targeting change of tender propositions may be launched at different phases of the public procurement procedure. Tender propositions in public procurement for food and agricultural products containing no criteria from Article 284 paragraph 7 certainly justify an appellate procedure, which may be launched solely by an interested co-operative registered as agricultural or fishery co-operative, and by no other legal subject. Therefore the Roman adage Vigilantibus jura (scriptasunt)! (Rights should be recognized to those who are vigilant!) quite accurately describes the situation of cooperatives interested in implementation of the said Public Procurement Law provision. Closer co-operation with responsible state bodies (particularly with the Ministry of Economy, Entrepreneurship and Crafts) and other interested parties could increase knowledge and implementation of public procurement legislation and thus strengthen co-operatives' legal position in public procurement procedures.

\subsection{Inadequate institutional support}

Next, participants' objections targeted inadequate institutional support to co-operatives, on the part of: (1) state administration, (2) the Croatian Center for Co-operative Entrepreneurship, chief governmental agency in charge of co-operatives, and (3) local selfgovernment units. Here we also delineate what our participants consider that these institutions should do in terms of information, consultative and other services to cooperatives. Due to weak institutional support, co-operative members often happen to make wrong choices during co-operative enterprise establishment and operation.

\subsubsection{State administration support}


Particular kind of co-operatives enjoys significant financial support from the state in Croatia. Currently, the establishment of each war veterans' co-operative is supported by the amount of $150.000,00 \mathrm{HRK}$ from the state budget, which approximately amounts to 20.000,00 EUR. The amount is to be used to cover the expenses related to the establishment of a cooperative (e.g. public notary fee) as well as the costs of necessary initial equipment. Yet, this does not seem to help the war veterans' co-operatives to be more successful, on average, than non-veteran ones, which shows that direct subsidies may not be the most appropriate type of institutional support to co-operatives. ${ }^{8}$ An example of a more commendable practice is the Ministry's of Economy, Entrepreneurship and Crafts recent call "Development of Cooperative Entrepreneurship", where grants were awarded to select co-operatives for targeted activities, such as eco-friendly production, energy efficiency, development of new products and services and other business process improvements (Ministry of Economy, Entrepreneurship and Crafts, 2018).

One of the most frequently raised objections regarding inadequate state institutional support concerned non-existence of a national strategy of co-operative development that could provide a more long-term vision of the sector and serve as a signpost in preventing systemic defects. Actually, taking into account a great diversity of the Croatian co-operative sector, there should be several strategies for co-operatives engaged in different areas. Research participants also strongly suggested that a strategic vision for development of co-operative entrepreneurship should be developed systematically, on the basis of bottom-up feedback from co-operatives to the governmental bodies, and not be simply imposed on co-operatives by the state:

"Co-operative entrepreneurship cannot develop by itself only. It should be developed systematically through the state apparatuses which follow science-based recommendations and us at the grassroots. I mean, bottom-up. If we go bottom-up, we should be listened to. Perhaps we do not always know how to say, present or articulate what bothers us, but it bothers us... The one who gave me resources, loan, etc. should see with me whether I manage to live, and not govern from a cabinet. Unfortunately, we have been governed from the cabinet." (18:22).

The Ministry of Agriculture has been criticized for not having a separate department devoted to co-operatives and their operation. Small co-operatives often cannot afford ecocertification, which also hampers marketing of their products. Whereas in France a comprehensive set of laws was introduced to provide farmers with incentives to grow organic foods, which also helped development of the COCEBI group - the leading French organic cereals co-operative (Mazzarol et al., 2013), there are no comparable legislative packages in Croatia and the country's great potential for eco-food production has been largely untapped as yet (Ham, Pap, \& Štimac, 2015). Research participants also complained of insufficient support to cooperatives in ensuring compliance with quality schemes for agricultural products and foodstuffs:

"There are some other obstacles related to insufficient market promotion of regional quality products, lack of internal standards for protection of autochthonous regional products, etc. I mean, there are always drawbacks and hindrances, but I think that we successfully cope with them." (26:22).

The last quote is also illustrative of entrepreneurial co-operative spirit, characterized by commitment and perseverance in the face of adversity, that was expressed by numerous research participants.

\subsubsection{Croatian Center for Co-operative Entrepreneurship}

Uncertainty mentioned in 4.1.1 has also been manifest in the operation of the Croatian Center for Co-operative Entrepreneurship (CCCE). Historically prior to the establishment of

\footnotetext{
${ }^{8}$ Golja and Novkovic (2014) noted that in 2012 only 5\% of veterans' co-operatives achieved positive financial results.
} 
the Center, a crucial umbrella institution was Co-operative Federation of Croatia (Zadružni savez Hrvatske in Croatian), which later changed its name into Croatian Co-operative Federation (Hrvatski zadružni savez), and subsequently got transformed into Croatian Agricultural Co-operative Federation (Hrvatski poljoprivredni zadružni savez). ${ }^{9}$ On the other hand, in the year 2002, the Croatian Federation of Co-operatives (Hrvatski savez zadruga) was established as a new umbrella institution. Some authors claim that the old umbrella institution bears the value of traditional representative body of Croatian co-operatives, the one created bottom-up, while the new umbrella institution was allegedly created top-down, by governmental representatives (Mataga, 2009). However, reasons for divisions between the old and the new umbrella institutions remain somewhat unclear and should be further explored.

The Center was established in 2014 as a continuation of the new umbrella institution. Unfortunately, by the end of 2018 it lost its status of an independent agency and became a unit of the Ministry of Economy, Entrepreneurship and Crafts. The Center was founded as a public institution for the purpose of promoting, representing and harmonizing cooperative interests in manifold ways through legal and policy proposals on the national and local levels. It offered educational, professional and consultancy programs at the national level. Yet another radical restructuring of the crucial institution established as recently as four years ago is indicative of incoherent and short-sighted planning with detrimental consequences for co-operatives.

CCCE as an agency was generally well recognized among co-operatives' members, yet many hold that the Center's programs should have been more in line with co-operatives' real needs, as illustrated by the following quote, which again raises the question of bottom-up feedback, and also expresses a need for co-operative networking and advocacy - another theme that recurs throughout participants' remarks:

"Concerning the CCCE, they organize various fairs where we may promote our domestic and international products that they co-finance. All that is praiseworthy, but we need much more than that, and much more concrete. It would be great it they would ask us what do we need, rather than impose 'here it is' and 'that's it'. I mean, it's important to recognize the values and needs of cooperatives, and not only how they see us. There is some dialogue, but our voices haven't been heard enough. We are not networked. In other words, you must have a sufficient number of voices, hands, for someone to hear you. Until you have enough members, until you are networked and connected, formally and informally, others can't hear you. Neither the Center for Co-operatives, nor the Chamber, nor ministries may hear you, while once you have strength and a number of members, that is you are connected, they most certainly will hear you." (33:21).

In the previous section we have seen that some research participants expressed a need for more scientifically-backed institutional support. However, the current level of analytical depth of CCCE's reports rarely exceeds that of the most basic descriptive statistics. Moreover, coordination between CCCE and the Croatian Bureau of Statistics was obviously lacking as the two institutions differed in the most basic data on, e.g., the number of existing co-operatives. Hence, there is ample room for enhanced co-operation between CCCE, currently transformed into a unit within the Ministry, and academic institutions.

\subsubsection{Local and regional self-government support}

Criticism expressed of local self-government units targeted differing levels of support among them:

\footnotetext{
${ }^{9}$ Even today the Internet search for Croatian Co-operative Federation (Hrvatski zadružni savez) leads to the website of the Croatian Agricultural Co-operative Federation (Hrvatski poljoprivredni zadružni savez), as the Croatian Agricultural Co-operative Federation retained the Internet domain of its predecessor (http://www.hzs.hr).
} 
"Structures certainly differ from municipality to municipality. In the municipality which I will not name now, where I would like to develop production, various public administration bodies are so disconnected that nobody knows what others are doing, and they do not inform you at all of some events, some upcoming seminars; you keep contact with them for the sake of co-operative entrepreneurship, but they do not tell you even that in ten days a seminar is scheduled, say, on a fund run by the Ministry of Regional Development etc. All of them are rather chaotic. However, this is not the case everywhere, for instance the Bjelovar-Bilogora County functions much more efficiently." (36:68).

Lack of coordination between local self-government units and co-operatives is typically illustrated by a problem facing agricultural co-operatives in the mountainous region of Lika. Many co-operatives in Lika have tried to grow autochthonous sorts of Lika potato. The sorts have been known for delicious taste and high nutritional value. However, due to mountainous relief and harsh climate, the yields of the Lika potato are lower than the yields of the sorts grown in northern, lowland parts of the country. The seeds of the Lika potato are also more expensive. Therefore, the production price of the Lika potato is somewhat higher. The region of Lika is one of the least developed Croatian regions and demand for the Lika potato is highest in the most developed regions. However, the co-operatives from Lika struggle to organize transport and distribution to other regions. Unfortunately, under the current circumstances, many tourist accommodation establishments in Lika, including those in the surroundings of the world-famous tourist destination Plitvice Lakes National Park, buy cheaper and less tasty potato from the lowland regions rather than high-quality autochthonous sorts produced by local co-operatives.

Dissatisfied with the current level of local and regional self-government support, research participants often invoked the principle of co-operation among co-operatives as the one that should also be applied to a wider society, particularly to the relations between co-operatives and the local and regional self-government units. Again, the participants are aware that they themselves need to invest more efforts in advocacy and lobbying:

"We do support each other and this support - what does it mean? This means that I will use your service because we are members [of the co-operative], and I will not use the service of someone who is not a member. As we use these services anyway, in that way we support each other. I expect the same from the local community and the state. For example, if the local community would contract, say, $1 \%$ of municipal services to the local co-operatives, we could employ much more workers. This is lobbying, this is something that we need to convince the local community of." (33:35)

However, there is again a counterexample from the region of Lika where a local co-operative contracted municipal snow removal services, but after two years the municipal authorities changed their mind and decided to provide these services themselves. Slightly different is an example of the textile recycling co-operative "Humana Nova" from Čakovec, which employs the disabled and members of other vulnerable groups. This social co-operative can collect only the textile not collected by municipal waste collection services. Compare this with the case of Belgium where local authorities regularly contract waste collection services to local contractors, among which the enterprises employing socially excluded persons enjoy special advantages (Posavec, 2018, pp. 232-233). How much easier would be for "Humana Nova" to operate in Belgium, instead of Croatia!

At the local and regional governance levels, Croatian co-operatives are, according to our research project data, mostly left to cope on their own. However, exactly at the local and regional level, necessary support should be offered to co-operatives by local and regional self-government units. Our participants claimed that the support is needed in: (1) distribution and selling of co-operatives' products; (2) use of co-operatives' services by economic, social, communal, educational, medical and cultural public institutions governed by the units of local and regional self-government, as well as by public companies under the ownership of the 
local and regional self-government units; (3) project elaboration for public tenders; (4) managerial capacities sharing; and (5) promotional opportunities.

An example of good practice from Virovitica-Podravina County shows how local selfgovernment units may catalyze the establishment of business cooperation between retail chain stores and co-operatives:

"When the retail chain store Plodine came to Virovitica in 2006, the local officials, fortunately, connected us with them, and they accepted us, and we are now, it can be said, one of the larger suppliers of agricultural products for the chain and for all their stores in Croatia." (19:27).

Another positive example was reported by a co-operative from the continental region of Slavonia, which received support from local self-government units to promote its products in tourist centers on the Adriatic Coast:

"At the very beginning, we sent a written notice to all the local self-government units, from municipalities and cities to tourist boards, so that they know that we exist. We sent a sort of specification and photos on a CD to their addresses, I sent over 200 such packages all throughout Croatia. OK, some did not respond, but some sent us invitations, within a month, to install sales stands in, for instance, Dubrovnik, Cavtat, Split, Baška Voda, Trogir, etc. We had to cover travel expenses, but all other expenses were covered by the local selfgovernment - it means that we did not have to pay for the stands to exhibit these Slavonian delicacies." (11:54).4.3 Inadequate financing mechanisms

Many research participants reported problems with getting adequate financing for their cooperative enterprises. Participants complained of high interest rates on bank loans and unnecessary difficulties when applying for bank loans, regardless of a co-operative's solvency. They also reported problems with inflexible purpose-specific bank loans:

"According to what l've seen on TV, let's say that it's acceptable and, in a way, beneficial - interest rates are maximally $3 \%$, in relation to everything else this is advantageous, but then you see that in Austria, when you're starting up, and if market assessments are positive, you can start with much lower interest rates. We are happy with more than twice higher and are still content. I'm going to see the next week... insurance instruments, realization, all these are now, allegedly, much simpler. But when I call them and say what I would like (...) I'd like to take a loan for rooms' refurbishment. 'Sorry, we don't have loans for rooms' refurbishment!' Refurbishment is not just purchasing a bed and a table, but I need to do the construction works, installations and this and that." (12:65).

Another research participant described how all of the twelve members of his co-operative had to use all their property as collateral to secure a bank loan of $100.000,00$ EUR. Needless to say, the total value of their property vastly exceeded the value of the loan, so he called such bank requirements "absurd" (7:70), yet they could not but comply.

Problems with financing mechanisms were among the prime movers for establishment of the Co-operative for Ethical Financing (ZEF) in 2014, which has since grown into the largest Croatian co-operative with more than 1.200 members and the combined annual income exceeding 250 million EUR (Co-operative for Ethical Financing, 2018). One of ZEF's primary goals is to establish the first Croatian Ethical Bank that would be fully owned by the cooperative's members. The bank is expected to offer better loan terms for borrowers, particularly those from the co-operative sector.

However, ZEF has also faced numerous obstacles in the course of establishing the Ethical Bank. Following ZEF's application, the Croatian National Bank (CNB) refused to issue a license for the establishment of the Ethical Bank on the grounds that ZEF "did not prove to secure the initial capital for the bank" (N1, 2017). ZEF also tried to acquire one of the smallest Croatian banks - "Tesla štedna banka", which went into troubles, but the offer was again rejected by CNB. Instead, "Tesla Štedna Banka" had to file for bankruptcy (Ćimić, 
2018). However, ZEF has not given up and, at the time of writing, it has been preparing another application to CNB for the establishment of the Ethical Bank.

\section{Discussion}

\subsection{Chaotic or rigged system?}

After reviewing a wide array of obstacles facing Croatian co-operatives today, one might ask: Why are there so many obstacles? Why are the institutional surroundings so unfavorable to cooperatives' development?

First, one might argue that the weaknesses of the Croatian institutional system are a more or less natural consequence of the country's turbulent recent history, including dissolution of the socialist system of former Yugoslavia, the ensuing war, disorderly transition and rapid, nontransparent privatization. In short, the country is less than thirty years old and its institutions have not yet been fully developed, so the institutional system is still weak and sometimes chaotic, but with time it will get better. This is the official view of the lagging Croatian socioeconomic development (e.g. Grabar Kitarović, 2018; Plenković, 2018) and there is a ring of truth in this "childhood illnesses" argument. Some of our study participants also noted that the notion of co-operatives is in public perception often wrongly associated with the remnants of the former political and economic system, which certainly does not help the sector's status among the key decision-makers, the state administration and the general public.

Yet, some examples from our study, e.g. the intentional destruction of a co-operative by a local clientelist patron, or an absurd requirement of a twelvefold collateral to a bank loan, cannot be explained by invoking the "childhood illnesses" argument only. To shed more light on these most striking examples, we have to return to the discussion of crony capitalism from Section 2 and observe that the Croatian co-operative sector generally fits poorly with cronyism. First, the vast majority of the Croatian co-operatives that survived predatory privatization are small and micro enterprises, which simply do not provide enough resources for clientelist extraction. Large firms, particularly those with substantial state-ownership shares, are much more convenient for influence peddling, awarding sinecure jobs to loyal clients, granting contracts in exchange for political favors, and other cronyist practices. Second, the very principles of co-operativism, particularly the principles of joint ownership and democratic control (ICA, 1995; Jussila, 2013), are by itself inimical to cronyism and therefore looked upon with suspicion by those who want to protect their privileged status. So, in contrast to the "childhood illnesses" argument, according to which abstract systemic defects are to blame for the current cooperatives' predicament, the "unfit-for-cronyism" argument points to the more concrete, but also more insidious processes working in the background. Further research is needed to show which of the two arguments better corresponds to the realities of the Croatian co-operative sector.

\subsection{A story of revival: Toward systemic integration of the Croatian co-operative sector}

Going back to the Croatia's neighboring country of Slovenia, one may observe that in the end of 2014 there were only 85 agricultural, forestry and fishing co-operatives (Avsec and Štromajer, 2015, p. 44), as some co-operatives gathering farmers with small parcels of fertile land were gradually integrated into larger co-operatives that include processing capacities such as dairies, breweries etc. ${ }^{10}$ Thus co-operatives need not sell raw products, but process and sell them as finished products. This systemic integration and organization enabled small farmers to survive and concentrate on yielding quality products, without having to think of EU regulations, applications for funds, distribution etc., as co-operatives have covered all such issues, and thus it enabled the sustainability of Slovenian agricultural production.

\footnotetext{
10 "An average agricultural and forestry co-operative, member of the Co-operative Union of Slovenia, generates an income of almost 10 million Euros, has a capital of 2.7 million Euros, employs 40 people, and affiliates 217 members." (Cooperative Union of Slovenia, 2018)
} 
How can Croatia's weak and fragmented co-operative sector be set on such a path? Proponents of the "childhood illnesses" argument would probably say that institutional maturation is a long and winding process and remedying all the external obstacles that we identified in previous sections will take considerable time, but, although with a time lag, the process will eventually converge.

There are, however, at least two objections to such a view. First, slow, long-term, systemic processes may be largely irrelevant for the real-world cooperatives' members, who live in the here and now and have to secure their means of subsistence immediately. Second, if we take into account that the "unfit-for-cronyism" argument may also be true, then the very notion of the crony system becoming, by itself, more hospitable to co-operatives becomes problematic. In other words, it is hard to expect that such a system would change without bottom-up pressures coming from the co-operatives themselves. Yet, the Croatian cooperatives are generally not strong enough to exert such pressures, so it may seem that we have come the full circle.

However, the principle of co-operation among co-operatives enabled some Croatian cooperatives to stimulate processes of co-operative self-organization, networking and integration. We have already mentioned the Co-operative for Ethical Financing (ZEF) and its efforts on the establishment of the Ethical Bank, which could offer better loan terms for the co-operative sector. Moreover, ZEF, with the help of other co-operatives, many of which are themselves members of ZEF, already offers a number of financial, educational, consulting, networking, accounting and book-keeping services for co-operatives, providing thus a potentially powerful platform for further bottom-up integration of the sector.

The foundation of ZEF and its integrative role within the Croatian co-operative sector have been welcomed by the study participants:

"You see, there is an intention in Croatia that one co-operative - the Co-operative for Ethical Financing - establishes a bank. I was one of the participants in its founding not really a founder, but I was there and I contributed to the initial capital. For me, it's fantastic..." (8:109).

Besides "horizontal" co-operation among co-operatives, such as co-operation in the supply chain and consortia-type arrangements, the issues of policy pressures, advocacy, cooperative sector development, and connections to the international co-operative movement all demand co-operation as well. The latter issues have generally been best dealt with "vertically", i.e. by co-operative federations (Birchall, 2003; Birchall \& Hammond Ketilson, 2009; Novkovic \& Golja, 2015). However, a few existing regional and branch co-operative associations in Croatia ${ }^{11}$ are rather weak. Yet, our study participants tended to view them more positively than the national-level CCCE, as they seem to be closer and more responsive to the co-operatives' immediate needs. ${ }^{12}$

Novkovic and Golja (2015) identified three main obstacles to the emergence of stronger cooperative federations in Croatia: (1) a wide gap between traditional and newly emerging cooperatives, (2) the lack of foreign investments, and (3) insufficient networking between cooperatives tied to social movements and the more traditional co-operatives. While there is no panacea to all these problems, we can cite again the example of ZEF, which has, in spite of all the mentioned difficulties, already succeeded to attract 19 co-operatives within its membership.

\section{Conclusions}

\footnotetext{
${ }^{11}$ According to the Record of Co-operatives and Co-operative Associations (Croatian Center for Cooperative Entrepreneurship, 2018), there are 7 regional and/or branch co-operative associations in Croatia.

${ }^{12}$ In Serbia, as well, "[g]eneral judgement is considerably more favorable regarding the work of the regional co-operative unions compared to the Co-operative Union of Serbia" (Ševarlić, Nikolić, \& Simmons, 2010, p. 31).
} 
Despite a long tradition of co-operative entrepreneurship in Croatia, and notwithstanding neighboring countries such as Italy and Slovenia with well-developed co-operative economy, the Croatian co-operative sector has recently been largely neglected. There is a substantial gap between a handful of successful co-operatives and a majority of relatively unsuccessful ones. In a country abounding with fertile land, and characterized by several decades of significant export of food and agricultural products, today the national import of food products by far exceeds the export, and the majority of Croatian co-operatives are marginal economic actors, working as weakly inter-related agents, accomplishing some local results at best.

This article presented results of the first comprehensive qualitative empirical study of the cooperative sector in more than twenty five years, to our best knowledge. The sample encompassed co-operatives of all kinds present in Croatia, from all traditional Croatian regions. Unlike the official annual national reports of co-operative entrepreneurship based entirely on survey data, we have undertaken qualitative research with a view to determine practitioners' perspective. In this paper we have been particularly focused on external obstacles to the sector's development brought up by our research participants. Whereas cooperatives supported by direct financial subsidies from the state have not developed into the most successful ones, some others receiving little or no direct support on the part of the state and local self-government units, such as Co-operative for Ethical Financing and social cooperative Humana Nova Čakovec, have turned out to be among the most successful Croatian co-operatives. Yet, the majority of co-operatives have remained weak and underdeveloped. We strove to examine and understand specific obstacles that practitioners encounter in daily co-operatives' working. We offered two possible explanations of the present state of affairs. Our research has confirmed that very many regulatory, institutional and financial obstacles stand in the way of co-operatives' development. Whenever possible, we proposed possible remedial actions to be taken. Our results suggest that the mechanical path of direct subventions should be replaced by more innovative forms of support. While on the national level they should be focused primarily on legislative and policy amendments making all relevant regulations more in line with specific needs of the co-operative sector, on the local level they should be focused primarily on facilitating closer co-operation and integration of local co-operatives and other interested agents, in line with specific needs of co-operatives in each local community. We maintain that the delineated state and local selfgovernment efforts should be strongly supplemented by co-operatives' own efforts at bottomup integration of the sector as the best way forward.

\section{Funding}

This work was supported by the University of Zagreb allotting a grant through the Faculty of Humanities and Social Sciences to the project "Success Factors and Cooperation Models of Co-operatives in Croatia", covering the expenses of preparatory phases, data gathering, analysis and interpretation.

\section{Acknowledgements}

The authors acknowledge the contributions of Davorka Matic and Anton Vukelić from the Department of Sociology, Faculty of Humanities and Social Sciences, University of Zagreb; Iva Marija Ilić, Karlo Karija, and other students of sociology at the same Department; Andrea Bekić from the Co-operative for Ethical Financing; and the two anonymous reviewers. Their help in various stages of preparation of this article is very much appreciated.

\section{References}

Avsec, F., \& Štromajer, J. (2015). Development and socioeconomic environment of Cooperatives in Slovenia. Journal of Co-operative Organization and Management, 3, 40-48. https://doi.org/10.1016/j.jcom.2015.02.004

Babić, Z., \& Račić, D. (2011). Co-operatives and social economy in Croatia: Trends, indicators and prospects in the European context. Sociologija i prostor, 49, 287-311. Full text in Croatian. https://doi.org/10.5673/sip.49.3.2 
Barney, J. B. (1991). Firm resources and sustained competitive advantage. Journal of Management, 17, 99-120. https://doi.org/10.1177/014920639101700108

Bijman, J. (2018). Exploring the sustainability of the cooperative model in dairy: The case of the Netherlands. Sustainability, 10, 2498. https://doi.org/10.3390/su10072498

Birchall, J. (2003). Rediscovering the cooperative advantage: Poverty reduction through selfhelp. Geneva: International Labour Organization. http://base.socioeco.org/docs/jb1.pdf Accessed 11 September 2019.

Birchall, J., \& Hammond Ketilson, L. (2009). Resilience of the cooperative business model in times of crisis. Geneva: International Labour Organization.

https://www.ilo.org/wcmsp5/groups/public/---ed emp/---

emp ent/documents/publication/wcms 108416.pdf Accessed 11 September 2019.

Bojić, B., \& Vapa-Tankosić, J. (2015). Legal status, role and importance of agricultural cooperatives in Serbia and in the European Union. Kultura polisa, 12, 395-410.

http://kpolisa.com/KP27/KP27-VI-1 BojicVapa.pdf Accessed 17 December 2018.

Borbaš, T., \& Mikšić, M. (2003). Poljoprivredne marketinške zadruge. Zagreb: Hrvatski zavod za poljoprivrednu savjetodavnu službu.

https://www.savjetodavna.hr/adminmax/publikacije/poljoprivredne marketinske zadruge slozeno.pdf Accessed 3 December 2018.

Braun, V., \& Clarke, V. (2006). Using thematic analysis in psychology. Qualitative Research in Psychology, 3, 77-101. https://doi.org/10.1191/1478088706qp063oa

CEPOR. (2017). Small and medium enterprises report Croatia - 2016. Zagreb: CEPOR SMEs and Entrepreneurship Policy Center. http://www.cepor.hr/wp-

content/uploads/2015/04/Cepor-izvjesce-2016-ENG-web.pdf Accessed 3 December 2018.

Cheney, G., Santa Cruz, I., Peredo, A. M., \& Nazareno, E. (2014). Worker cooperatives as an organizational alternative: Challenges, achievements and promise in business governance and ownership. Organization, 21, 591-603.

https://doi.org/10.1177/1350508414539784

Chroneos Krasavac, B., \& Petković, G. (2015). Cooperatives in Serbia - Evolution and current issues. Economics of Agriculture, 62, 723-736.

https://doi.org/10.5937/ekoPolj1503723C

Cogeca. (2010). Agricultural co-operatives in Europe: Main issues and trends. Brussels:

European agri-cooperatives (Cogeca). http://www.agro-

alimentarias.coop/ficheros/doc/03020.pdf Accessed 3 December 2018.

Co-operative for Ethical Financing. (2018). Who we are. https://www.zef.hr/en/o-nama/o-zefu Accessed 6 December 2018.

Cooperative Union of Slovenia. (2018). http://www.zadruzna-

zveza.si/english/cooperative union of slovenia.html Accessed 3 December 2018.

Croatian Bureau of Statistics. (2018). Number and structure of business entities, September

2018. First Release, 55, 11.1.1/3. https://www.dzs.hr/Hrv Eng/publication/2018/11-01-

0103 2018.htm Accessed 14 December 2018.

Croatian Center for Co-operative Entrepreneurship. (2017). Godišnje izvješće o stanju zadružnog poduzetništva za 2016. godinu.

http://zadruge.coop/upload data/site files/15685717151133565576743222798 godisnjeizvjesce-o-stanju-zadruznog-poduzetnistva-2016.pdf Accessed 5 October 2018.

Croatian Center for Co-operative Entrepreneurship. (2018). Record of co-operatives and cooperative aassociations. http://zadruge.coop/en/record-of-co-operative-and-co-operativeassociation\&pravni oblik=1\&naziv=\&oib=\&zupanija=\&usluge=\&trazi=Search Accessed 5 October 2018. 
Cvetko, J. (1908). Što je Hrvatska seljačka zadruga i kako se osniva. Zagreb: Tisak Dioničke tiskare.

Ćimić, I. (2018). Banka koja ne pljačka htjela spasiti Tesla banku, no žale se da ih je zaustavila hrvatska birokracija. https://www.index.hr/Vijesti/clanak/banka-koja-ne-pljackahtjela-spasiti-tesla-banku-no-zale-se-da-ih-je-zaustavila-hrvatska-birokracija/1037480.aspx Accessed 8 December 2018.

Dalić, M. (2018). Agrokor: Slom ortačkog kapitalizma. Zagreb: Hanza media.

Davis, G. F., \& Cobb, J. A. (2010). Resource dependence theory: Past and future. In C. Bird Schoonhoven, \& F. Dobbin (Eds.), Stanford's organization theory renaissance, 1970-2000 (Research in the Sociology of Organizations, Volume 28, pp. 21-42). Bingley: Emerald Group Publishing. https://doi.org/10.1108/S0733-558X(2010)0000028006

Defilippis, J. (2005). Development of the family holdings in Croatia and the co-operative movement. Sociologija sela, 43, 43-59. Full text in Croatian. https://hrcak.srce.hr/32012 Accessed 17 December 2018.

Franičević, V., \& Bićanić, I. (2007). EU accession and Croatia's two economic goals: Modern economic growth and modern regulated capitalism. Southeast European and Black Sea Studies, 7, 637-663. https://doi.org/10.1080/14683850701726104

Golja, T., \& Novkovic, S. (2014). Determinants of co-operative development in Croatia. In L. Hammond Ketilson, \& M.-P. Robichaud Villettaz (Eds.), Co-operatives' power to innovate: Texts selected from the International Call for Papers (pp. 15-26). Lévis: International Summit of Cooperatives.

Grabar Kitarović, K. (2018). Speech of the President of the Republic of Croatia Kolinda Grabar Kitarović on Süddeutsche Zeitung Economic Summit. Berlin, 14 November 2018. https://www.youtube.com/watch?v=TF4OlIGG6Es Accessed 7 December 2018.

Guest, G., MacQueen, K. M., \& Namey, E. E. (2011). Applied thematic analysis. Thousand Oaks: SAGE.

Ham, M., Pap, A., \& Štimac, H. (2015). Eco-food production and market perspectives in Croatia. In Z. Šegetlija, \& D. Dujak (Eds.), Proceedings of The 15th International Scientific Conference Business Logistics in Modern Management, Osijek, 15 October 2015 (pp. 93109). Osijek: Faculty of Economics.

https://hrcak.srce.hr/ojs/index.php/plusm/article/view/3875 Accessed 17 December $2018 .$.

ICA. (1995). International Cooperative Alliance Statement on the co-operative identity, values \& principles. https://www.ica.coop/en/cooperatives/cooperative-identity Accessed 17 December 2018.

Ivanković, Ž. (2018). Slučaj Agrokor: Privatizacija i crony kapitalizam. Zagreb: Jesenski i Turk.

Jussila, I. (2013). Inaugural editorial. Journal of Co-operative Organization and Management, 1, 1-5. https://doi.org/10.1016/i.jcom.2012.11.001

Kotarski, K., \& Petak, Z. (2019). Croatia's post-communist transition experience: The paradox of initial advantage turning into a middle-income trap. In Z. Petak, \& K. Kotarski (Eds.), Policy-making at the European periphery: The case of Croatia (pp. 1-25). Cham: Palgrave Macmillan. https://doi.org/10.1007/978-3-319-73582-5 1

Lambru, M., \& Petrescu, C. (2014). Surviving the crisis: Worker cooperatives in Romania. Organization, 21, 730-745. https://doi.org/10.1177/1350508414537807

Mataga, Ž. (1995). Seljak i zadruga. Bjelovar: Prosvjeta. 
Mataga, Ž. (2005). Agricultural co-operative movement in Croatia: Development and core issues. Sociologija sela, 43, 17-42. Full text in Croatian. https://hrcak.srce.hr/31972 Accessed 4 December 2018.

Mataga, Ž. (2009). Etičke vrijednosti i gospodarski značaj zadrugarstva. Zagreb: Vlastita naklada.

Mataga, Ž. (Ed.) (2014). 150 godina poljoprivrednog zadrugarstva Hrvatske (1864.-2014.). Zagreb: Hrvatski poljoprivredni zadružni savez.

Matijašević, A. (2005). Co-operative laws in Croatia: Development and problems of legislation concerning the agricultural co-operatives. Sociologija sela, 43, 153-170. Full text in Croatian. https://hrcak.srce.hr/32877 Accessed 4 December 2018.

Mazzarol, T., Mamouni Limnios, E., \& Reboud, S. (2013). Co-operatives as a strategic network of small firms: Case studies from Australian and French co-operatives. Journal of Co-operative Organization and Management, 1, 27-40.

https://doi.org/10.1016/i.jcom.2013.06.004

Ministry of Economy, Entrepreneurship and Crafts. (2018). Zadrugama dodijeljeno 2,5 milijuna kuna bespovratnih sredstava. https://www.mingo.hr/page/zadrugama-dodijeljeno-25-milijuna-kuna-bespovratnih-sredstava Accessed 23 December 2018.

N1. (2017). HNB odbio dati dozvolu za rad Etičnoj banci. http://hr.n1info.com/Biznis/a197662/HNB-odbio-dati-dozvolu-za-rad-Eticnoj-banci.html Accessed 8 December 2018.

Novkovic, S. (2008). Defining the co-operative difference. The Journal of Socio-Economics, 37, 2168-2177. https://doi.org/10.1016/..socec.2008.02.009

Novkovic, S., \& Golja, T. (2015). Cooperatives and civil society: Potential for local cooperative development in Croatia. Journal of Entrepreneurial and Organizational Diversity, 4, 153-169. https://www.euricse.eu/wp-content/uploads/2016/06/7novkovicgolia13aug2015.pdf Accessed 11 September 2019.

Official Gazette. (2011). Zakon o zadrugama. Official Gazette of the Republic of Croatia, 34. https://narodne-novine.nn.hr/clanci/sluzbeni/2011 $03 \quad 34$ 764.html Accessed 17 December 2018.

Pavličević, D. (2010). Hrvatske kućne/obiteljske zadruge. Volumes I and II. Zagreb: Golden Marketing - Tehnička knjiga.

Pejnović, D., Radeljak Kaufmann, P., \& Lukić, A. (2016). Development and contemporary characteristics of agricultural cooperatives in the area of Croatia. Croatian Geographical Bulletin, 78, 5-48. https://doi.org/10.21861/HGG.2016.78.02.01

Petak, A. (2005). Izazovi poljoprivrednog zadrugarstva - izazovi Hrvatske. Sociologija sela, 43, 5-16. https://hrcak.srce.hr/31963 Accessed 4 December 2018.

Pfeffer, J., \& Salancik, G. R. (1978). The external control of organizations: A resource dependence perspective. New York: Harper \& Row.

Plenković, A. (2018). Speech of Prime Minister of the Republic of Croatia Andrej Plenković in the European Parliament. Strasbourg, 6 February 2018.

https://vlada.gov.hr/UserDocsImages//Vijesti/2018/02\%20velja\%C4\%8Da/6\%20velja\%C4\%8 De//Speech\%20Plenkovic\%20Strasbourg\%206\%202\%202018.pdf Accessed 7 December 2018.

Posavec, R. (2018). Pank poduzetnici. Čakovec: ACT Grupa.

Puljiz, V. (1992). Communal joint families, zadrougas, and "Zadruga" process of modernization in the modernization of the Croatian society. Sociologija sela, 30, 147-154. Full text in Croatian. https://hrcak.srce.hr/119762 Accessed 17 December 2018. 
Restakis, J. (2010). Humanizing the economy: Co-operatives in the age of capital. Gabriola Island: New Society Publishers.

Reynolds, B. J. (2000). The one member-one vote rule in cooperatives. Journal of Cooperatives, 15, 47-62.

http://ageconsearch.umn.edu/record/46411/files/Volume\%2015\%20Article\%204.pdf

Accessed 11 November 2018.

Rybnikova, I., \& Hartz, R. (2014). Participation and economic growth in cooperatives:

Empirical explorations of a (supposedly) well-known relationship. Presentation at the $4^{\text {th }}$ International Degrowth Conference, Leipzig, 2-6 September 2014.

https://www.degrowth.info/wp-

content/uploads/2015/08/Degrowth2014 Rybnikova Hartz Participation-and-economicgrowth-in-cooperatives-Empirical-explorations-of-a-supposedly-well-known-relationship.pdf Accessed 16 November 2018.

Schlemper, K. (2014). Machinery rings - a mechanisation concept of African farmers?. Rural 21, 2, 23. https://e-

I.unifi.it/pluginfile.php/66819/mod resource/content/1/Machinery\%20Rings.pdf Accessed 16 October 2018.

Sivertsen, S. (1996). Governance issues seen from a management perspective. Review of International Co-operation, 89, 34-36.

http://www.uwcc.wisc.edu/icic/orgs/ica/pubs/review/ICA-Review-Vol--89-No--4-19961/Governance-Issues-Seen-From-a-Management1.html Accessed 16 November 2018.

Stanojević, I. (2015). Analiza zadružnog sustava u 2014. godini. Agronomia Croatica, 5, 5157. https://hrcak.srce.hr/143686 Accessed 17 December 2018.

Stiglitz, D. J. (2009). Moving beyond market fundamentalism to a more balanced economy, Annals of Public and Cooperative Economics, 80, 345-360. https://doi.org/10.1111/i.14678292.2009.00389.x

Storey, J., Basterretxea, I., \& Salaman, G. (2014). Managing and resisting 'degeneration' in employee-owned businesses: A comparative study of two large retailers in Spain and the United Kingdom. Organization, 21, 626-644. https://doi.org/10.1177/1350508414537624

Street, C. T., \& Cameron, A.-F. (2007). External relationships and the small business: A review of small business alliance and network research. Journal of Small Business Management, 45, 239-266. https://doi.org/10.1111/j.1540-627X.2007.00211.x

Stubbs, P., \& Zrinščak, S. (2015). Citizenship and social welfare in Croatia: Clientelism and the limits of 'Europeanisation'. European Politics and Society, 16, 395-410. https://doi.org/10.1080/23745118.2015.1061798

Ševarlić, M. M., Nikolić, M. M., \& Simmons, R. (2010). Agricultural cooperatives and their membership in cooperative unions in Serbia. APSTRACT (Applied Studies in Agribusiness and Commerce), 10, 25-32. https://doi.org/10.19041/apstract/2010/3-4/4

Šoljić, K., Pavličević, J., \& Milas, Z. (2005). Cooperatives in Bosnia and Herzegovina: A step closer to Europe. Agronomski glasnik, 67, 393-425. Full text in Croatian. https://hrcak.srce.hr/2265 Accessed 17 December 2018.

Šonje, V. (2019). The competitiveness of the Croatian economy: A comparison of private and public sector enterprises. In Z. Petak, \& K. Kotarski (Eds.), Policy-making at the European periphery: The case of Croatia (pp. 207-226). Cham: Palgrave Macmillan. https://doi.org/10.1007/978-3-319-73582-5 11

Švarc, J., \& Lažnjak, J. (2017). Innovation culture in crony capitalism. Does Hofstede's model matter? Zagreb: Ivo Pilar Institute of Social Sciences. 
Tratnik, M., Radinović, S., \& Žutinić, Đ. (2007). Cooperatives in Croatia: Challenges to stability of farms. Agronomski glasnik, 69,63-76. Full text in Croatian.

https://hrcak.srce.hr/18202 Accessed 17 December 2018. 